\title{
Optimization on process of ripe canistel (Pouteria campechiana) fruit flour based on several quality characteristics
}

\section{Otimização do processamento de farinha de canistel maduro (Pouteria campechiana) baseada em características de qualidade}

\author{
Sri Rejeki Pertiwi ${ }^{1 *}$ (D), Siti Nurhalimah ${ }^{1}$ Aminullah A. ${ }^{1 *}$ (D) \\ ${ }^{1}$ Djuanda University, Faculty of Halal Food Science, Department of Food Technology and Nutrition, Bogor/West \\ Java - Indonesia
}

${ }^{*}$ Corresponding Author: Aminullah A., Djuanda University, Faculty of Halal Food Science, Department of Food Technology and Nutrition, Jl. Tol Ciawi 01, PO Box: 16720, Bogor/West Java - Indonesia, e-mail: aminullah@unida.ac.id

Cite as: Pertiwi, S. R., Nurhalimah, S., \& Aminullah, A. (2020). Optimization on process of ripe canistel (Pouteria campechiana) fruit flour based on several quality characteristics. Brazilian Journal of Food Technology, 23, e2019056. https://doi.org/10.1590/1981-6723.05619

\begin{abstract}
Canistel is a high carotenoid fruit which can be converted into gluten-free flour. The objective of the research was to determine the selected soaking and drying processes in ripe canistel fruit flour based on its sensory, phytochemical, as well as physical and chemical characteristics. The research methods consisted of determining sensory and phytochemical characteristics by soaking ripe canistel fruit in $\mathrm{NaCl}$ and citric acid solutions as well as determining the physical and chemical characteristics of the flour by various drying temperatures and duration. The results showed that $\mathrm{NaCl}$ solution was better to eliminate the bitter taste and maintain the orange color of canistel fruit flour. Furthermore, drying temperature affected moisture, carbohydrate, fiber, starch, and energy contents. However, it did not affect bulk density, protein, fat, ash, sugar, and beta-carotene contents. These data also confirmed that soaking in $\mathrm{NaCl}$ solution of $7.5 \%$ for 30 minutes followed by drying at $40^{\circ} \mathrm{C}$ for 6 hours produced best canistel fruit flour.
\end{abstract}

Keywords: Flour process; Physicochemical; Phytochemical; Pre-treatment; Ripe canistel; Sensory.

\section{Resumo}

Canistel é uma fruta com alto teor de carotenoides, que pode ser convertida em uma farinha sem glúten. O objetivo da pesquisa foi avaliar os processos de maceração e secagem na produção de farinha de canistel madura, em termos de suas características sensoriais, fitoquímicas, físicas e químicas. Determiram-se as características sensoriais e fitoquímicas do canistel macerado em soluç̃es de $\mathrm{NaCl}$ e ácido cítrico, bem como as características físicas e químicas da farinha obtida em diferentes temperaturas e tempos de secagem. Os resultados mostraram que a maceração na solução de $\mathrm{NaCl}$ eliminou melhor o amargor e manteve mais a cor laranja da farinha de canistel. Além disso, a temperatura de secagem influenciou os teores de umidade, de carboidratos, fibras, amido, além do conteúdo calórico. No entanto, isso não afetou a densidade aparente, teores de proteínas, gordura, cinzas, açúcar 
e beta-caroteno. Os resultados também mostram que a maceração na solução de $\mathrm{NaCl}$ a $7,5 \%$ por 30 minutos, seguido de secagem a $40{ }^{\circ} \mathrm{C}$ por 6 horas produziu a melhor farinha de canistel.

Palavras-chave: Processo produção de farinha; Propriedades físico-químicas; Propriedades fitoquímicas; Prétratamento; Canistel maduro; Sensorial.

\section{Introduction}

Canistel (Pouteria campechiana) is a plant originating from Mexico that can grow in tropical and subtropical climates; in Indonesia, it is found in many areas of West Java and it is relatively cheap. Canistel fruit has an interesting yellow color that comes from carotenoid components. According to Lanerolle et al. (2008) and Costa et al. (2010), canistel fruit is an essential source of carotenoids in which the fruit has a total carotenoid content of 1.9-23.5 mg/g dry weight. In addition, Kong et al. (2013) reported that the canistel fruit extract using $70 \%$ ethanol is a source of phenolic and flavonoid compounds. Canistel fruit is often used directly as dessert, salad, ice cream, and pastry flavor, as well as juice (Lim, 2012), a spread (Morton, 1987), and ketchup (Malinao et al., 2017). Canistel fruit, when used as a drink or eaten directly has a fairly short shelf life of about 10 days (Morton, 1987). Therefore, it is necessary to use a preservation method to extend its shelf life, and one method of preservation is flour processing using a drying machine. The use of canistel fruit flour will provide several advantages such as the provision of non-gluten flour, the canistel fruit preservation, and the use of local food resources. Paragados (2014) suggested that canistel fruit flour was successfully prepared by sun-drying or conventional methods and it was used in the production of cookies with favorable results, according to the panelists. Pertiwi et al. (2018) used canistel fruit flour as an ingredient in steamed brownies. However, conventional drying has some weaknesses, such as the difficulty to control the process and that it may be easily contaminated. In addition, according to Indrajaya (2017), canistel fruit flour still has a bitter taste coming from fruit sap.

One method to eliminate bitter taste in canistel flour is the soaking process before drying (pre-drying treatment). Citric acid and salt solution can be used to eliminate sap on tubers and fruits. Mayasari (2010) reported that citric acid and salt $(\mathrm{NaCl})$ could be used to eliminate sap on taro flour and used citric acid of $0.1 \mathrm{M}, 0.3 \mathrm{M}$, and $0.5 \mathrm{M}$ for 5 and 10 minutes as well as $\mathrm{NaCl}$ of $5 \%, 7.5 \%$, and $10 \%$ for 30 and 60 minutes, and the results showed that the optimum treatment was soaking in $\mathrm{NaCl}$ of $10 \%$ for 60 minutes. Suprapto (2006) stated that the treatment of sap elimination on kepok plantain using salt solution was a better method compared to the blanching treatment. Soaking in salt solution of $7.5 \%$ was also done by Widiawan et al. (2013) in kimpul (Xanthosoma sagittifolium) starch processing. In addition, another parameter in canistel fruit flour is to maintain its yellow color during the soaking process. This can be conducted using a low drying temperature of less than $50^{\circ} \mathrm{C}$. According to Lidiasari et al. (2006), high temperatures and long drying duration were the main factors in color changes of materials. From these problems, it is necessary to develop canistel fruit flour to remove the bitter taste and retain sensory properties, especially its interesting orange color. In addition, data on both the processes and the properties of canistel fruit flour have not been fully documented in the literature. Therefore, the objective of this research was to study the sensory, phytochemical, as well as physical and chemical properties of canistel fruit flour using various soaking and drying processes as well as to obtain an optimized or selected process on ripe canistel fruit flour based on those properties. 


\section{Material and methods}

The research consisted of two stages namely, the determination of the solution concentration and soaking duration as the pre-drying process and the determination of drying temperature and duration. In the first stage, ripe canistel fruit was peeled and thinly sliced before soaked in $\mathrm{NaCl}$ and citric acid solutions, which were used based on Mayasari (2010) method in the manufacture of taro flour. Soaking process of ripe canistel fruit in citric acid used concentration of $0,0.1,0.3$, and $0.5 \mathrm{M}$ for 5 and $10 \mathrm{~min}$, respectively, where soaking in $\mathrm{NaCl}$ solution used $0,5 \%, 7.5 \%, 10 \%$ for 30 and $60 \mathrm{~min}$, respectively. After the soaking process, ripe canistel fruit was washed, drained, and then dried in an electric food dehydrator type MKS-DR10 (manufacturer of PT Toko Mesin Maksindo, Indonesia) at $60{ }^{\circ} \mathrm{C}$ for 5 hours to reach final moisture of less than $10 \%$. After that, the dried fruit slices were milled using disc mill type FFC-15 and sieved using 100 mesh siever. Then, the sensory and phytochemical properties of canistel fruit flour were analyzed.

The selected solution concentration and duration for the soaking process were determined based on the results of sensory and phytochemical tests. The sensory evaluation was conducted using a quantitative description analysis (QDA) method by ten trained panelists. The sensory attributes of color and taste were developed through focus group discussion (FGD) and panelists gave their responses on 10-cm unstructured line scale where $0=$ none and $10=$ bitter for bitter taste as well as $0=$ pale orange and $10=$ bright orange for orange color (Meilgaard et al., 1999). Phytochemical tests were conducted in accordance with Mehraj et al. (2015) procedure for alkaloids using Mayer's reagent, flavonoid using alkali $(\mathrm{NaOH})$ test, and tannin using $2 \%$ of $\mathrm{FeCl}_{3}$ reagent.

The second stage, like the first processing stage, canistel fruit was thinly sliced, then soaked into the selected soaking treatment in the first stage. It was washed, drained, and then dried in electric food dehydrator type MKS-DR10 using various drying temperatures and duration at temperatures of 30,40 , and $50{ }^{\circ} \mathrm{C}$ for 6 and 8 hours. After that, it was milled and sieved, and then canistel fruit flour's sensory, physical and chemical properties were analyzed. All treatments in this study were conducted with two replications using a factorial complete randomized design of two-factor.

The measurements in this study were physical, chemical, phytochemical and sensory tests. The physical tests of canistel fruit flour included yield (Association of Official Analytical Chemists, 2010) and bulk density (Okezie \& Bello, 1988) tests. The chemical tests included moisture content (Association of Official Analytical Chemists, 2010), protein (Association of Official Analytical Chemists, 2010), fat (Association of Official Analytical Chemists, 2010), carbohydrates (Winarno, 1997), sugar (Association of Official Analytical Chemists, 2010), fiber (Association of Official Analytical Chemists, 2010), ash (Association of Official Analytical Chemists, 2010), beta-carotene (Association of Official Analytical Chemists, 2010), and starch (Badan Standardisasi Nasional, 2011) tests, and qualitatively phytochemical tests included alkaloid, flavonoid, and tannin tests (Mehraj et al., 2015). The data were analyzed using a one-way analysis of variance in the SPSS ${ }^{\circledR}$ program version 21 and Duncan's posthoc test.

\section{Results and discussion}

\subsection{Determination of the solution, concentration and soaking duration as the pre-drying process}

Mehraj et al. (2015) reported that phytochemical compounds in canistel fruit sap were tannins, flavonoids, and alkaloids. According to Crozier et al. (2006), raw canistel fruit usually contained more tannins and flavonoids than ripe fruit so that raw fruit tended to have a bitter taste. Table 1 shows the phytochemical test of canistel fruit flour after the soaking process with acid and $\mathrm{NaCl}$ solutions. 
Table 1. Phytochemical contents of canistel fruit by soaking in citric acid and $\mathrm{NaCl}$ solutions.

\begin{tabular}{|c|c|c|c|c|c|c|c|c|c|}
\hline \multirow{5}{*}{$\begin{array}{l}\text { Soaking in } \\
\text { citric acid } \\
\text { solution }\end{array}$} & \multirow{2}{*}{$\begin{array}{c}\text { Phytochemical } \\
\text { compound }\end{array}$} & \multicolumn{8}{|c|}{ Citric acid concentration $(\mathrm{M})$; soaking duration (min) } \\
\hline & & $0 ; 5$ & $0 ; 10$ & $0.1 ; 5$ & $0.1 ; 10$ & $0.3 ; 5$ & $0.3,10$ & $0.5,5$ & $0.5,10$ \\
\hline & Tannin & +++ & +++ & +++ & +++ & +++ & +++ & +++ & +++ \\
\hline & Flavanoid & ++ & ++ & + & ++ & ++ & ++ & + & + \\
\hline & Alkaloid & +++ & +++ & +++ & +++ & + & + & ++ & ++ \\
\hline \multirow{5}{*}{$\begin{array}{l}\text { Soaking in } \\
\mathrm{NaCl} \text { solution }\end{array}$} & Phytochemical & \multicolumn{8}{|c|}{$\mathrm{NaCl}$ concentration $(\%)$; soaking duration $(\mathrm{min})$} \\
\hline & compound & $0 ; 30$ & $0 ; 60$ & $5 ; 30$ & $5 ; 60$ & $7.5 ; 30$ & $7.5 ; 60$ & $10 ; 30$ & $10 ; 60$ \\
\hline & Tannin & +++ & +++ & +++ & +++ & +++ & +++ & +++ & +++ \\
\hline & Flavanoid & ++ & ++ & + & + & - & + & - & + \\
\hline & Alkaloid & +++ & +++ & +++ & ++ & - & + & + & + \\
\hline
\end{tabular}

Heavily present: +++; slightly present: ++; present: +; absent: - .

Table 1 shows that no changes were found in tannin content in canistel fruit. According to Makkar et al. (1999), tannin compounds have a large molecular weight in which tannins could dissolve in strong acids such as hydrochloric acid and decompose at a temperature of $98.8^{\circ} \mathrm{C}$. The citric acid and $\mathrm{NaCl}$ solutions with various concentrations and soaking duration at room temperature can not dissolve tannin compounds. Table 1 also shows a decrease in alkaloid and flavonoid contents with the higher concentration of citric acid and $\mathrm{NaCl}$. Robinson (1995) explained that most flavonoids were found in the form of glycosides and could be extracted or dissolved in water. These lower compounds are related to lower bitter taste, and this is supported by sensory tests on canistel fruit as shown in Table 2.

Table 2. Sensory test on the bitter taste of canistel fruit after the soaking process in citric acid and $\mathrm{NaCl}$ solutions.

\begin{tabular}{|c|c|c|c|c|c|}
\hline \multirow{5}{*}{$\begin{array}{l}\text { Citric acid } \\
\text { solution }\end{array}$} & Concentration (M) & Score & \multirow{5}{*}{$\mathrm{NaCl}$ solution } & Concentration (\%) & Score \\
\hline & 0 & $8.6^{\mathrm{a}}$ & & 0 & $7.8^{p}$ \\
\hline & 0.1 & $4.7^{\mathrm{b}}$ & & 5 & $3.1^{\mathrm{q}}$ \\
\hline & 0.3 & $4.5^{\mathrm{b}}$ & & 7.5 & $1.9^{q}$ \\
\hline & 0.5 & $4.4^{\mathrm{b}}$ & & 10 & $1.9^{\mathrm{q}}$ \\
\hline
\end{tabular}

Different superscript letters in one column show significant differences at the $5 \%$ level; lower score means lower bitter taste.

Table 2 shows a significant decrease in the bitter taste score when canistel fruit is soaked in either citric acid or $\mathrm{NaCl}$ solution compared to pure water (no citric acid or $\mathrm{NaCl}$ addition). Besides, it indicates that a higher solution concentration leads to a lower bitter score, where soaking in $\mathrm{NaCl}$ is better to decrease the bitter taste since its score is closer to 0 (none/no bitter taste). As previously explained, the decrease in the bitter taste score through this hedonic test is related to the decrease of phytochemical compounds in canistel fruit. In addition to the parameter of the bitter taste, the aspect of color changes that occur due to soaking in $\mathrm{NaCl}$ and citric acid solutions is also studied.

Table 3. Soaking process in citric acid and $\mathrm{NaCl}$ on the orange color of canistel fruit flour.

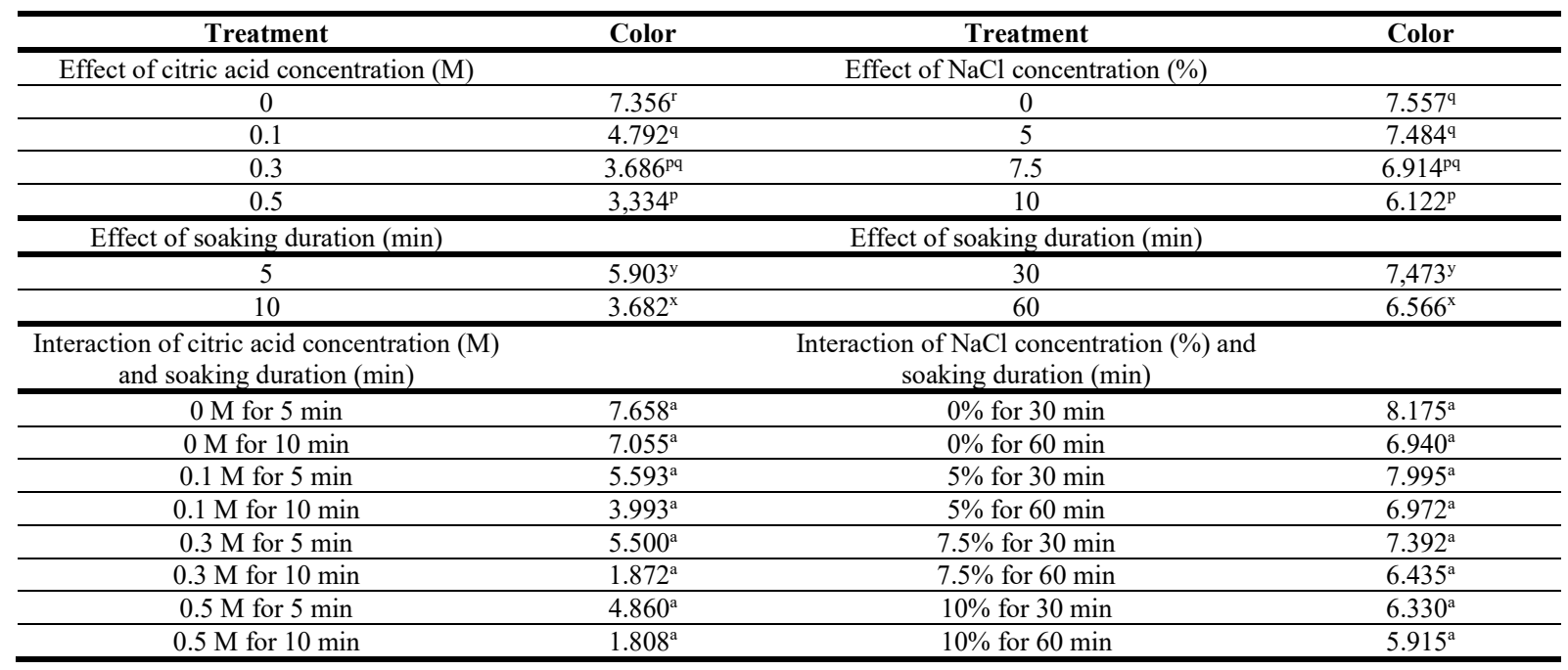

Different superscript letters in one column show significant differences at the $5 \%$ level; lower score means paler orange color. 
Table 3 shows that the higher concentration of citric acid and the longer soaking process leads to the lower orange color of canistel fruit flour. This is because the beta-carotene is dissolved in acidic solution. According to Fennema (1996), beta-carotene could be damaged by the acidic soaking process where this condition will trigger the "all-trans" isomerization into "cis". In contrast, soaking canistel fruit in $\mathrm{NaCl}$ solution does not dissolve beta-carotene. Clifford et al. (2014) reported that salt solution did not affect beta-carotene content in sweet potato. Though, the longer soaking process leads to the lower orange color. Table 3 also confirms that the use of $\mathrm{NaCl}$ solution in the soaking process gives better properties than the citric acid solution. Soaking canistel fruit in a $\mathrm{NaCl}$ solution can significantly reduce the phytochemical contents, which leads to a lower bitter taste score and maintains the orange color or beta-carotene content. Soaking in $\mathrm{NaCl}$ solution of $7.5 \%$ for 30 minutes is the selected treatment which can maintain the orange color as well as reduce the bitter taste. This treatment is then applied in canistel fruit flour processing using various drying temperatures and duration.

\subsection{Determination of drying temperature and duration in canistel fruit flour processing}

Table 4. The yield and bulk density of canistel fruit flour.

\begin{tabular}{ccc}
\hline Drying temperature $\left({ }^{\circ} \mathbf{C}\right)$ & Yield (\%) & Bulk density (g/L) \\
\hline 30 & $29.7450^{\mathrm{a}}$ & $0.7639 \mathrm{p}$ \\
\hline 40 & $26.3225^{\mathrm{b}}$ & $0.7890^{\mathrm{p}}$ \\
\hline 50 & $26.2575^{\mathrm{b}}$ & $0.7892^{\mathrm{p}}$ \\
\hline
\end{tabular}

Different superscript letters in one column show significant differences at the $5 \%$ level.

The yield is the amount of final product produced after the raw material undergoes a series of processing. Drying temperature significantly affects the yield of canistel fruit flour, while the drying duration and the interaction of two factors have no significant effect on it (Table 4). The higher drying temperature leads to a lower yield. This can happen because of a higher drying temperature results on lower moisture content. Taib et al. (1988) and Desrosier (1988) stated that the higher the drying temperature on the material, the more water evaporated from the material which impacts less weight of the material and lowers the yield. This is consistent with the results of the moisture content of canistel fruit flour at $30{ }^{\circ} \mathrm{C}$ that is greater than that at 40 and $50{ }^{\circ} \mathrm{C}$ (Table 5). The bulk densities of canistel fruit flour in this study are in the range of 0.7639 to $0.7892 \mathrm{~g} / \mathrm{L}$, where there are no significant differences with all applied treatments (Table 4). According to Kurozawa et al. (2009), bulk density determines the characteristics of the final product as the volume of storage obtained from the drying process. Bulk density is influenced by several factors such as particle size, material properties, material composition, and molecules degradation in the material due to processing. Drying duration and interaction between drying temperature and duration have no significant effect on the bulk density of canistel fruit flour.

Table 5. Chemical properties of canistel fruit flour with various drying temperature.

\begin{tabular}{|c|c|c|c|c|c|c|c|c|c|c|}
\hline $\begin{array}{c}\text { Temp } \\
\left({ }^{\circ} \mathrm{C}\right) \\
\end{array}$ & $\begin{array}{c}\text { Moisture } \\
(\%) \\
\end{array}$ & $\begin{array}{l}\text { Ash } \\
(\%) \\
\end{array}$ & $\begin{array}{c}\text { Protein } \\
(\%) \\
\end{array}$ & $\begin{array}{c}\text { Sugar } \\
(\%)\end{array}$ & $\begin{array}{c}\text { Carbo } \\
(\%) \\
\end{array}$ & $\begin{array}{c}\text { Starch } \\
(\%)\end{array}$ & $\begin{array}{c}\text { Fiber } \\
(\%)\end{array}$ & $\begin{array}{l}\text { Fat } \\
(\%) \\
\end{array}$ & $\begin{array}{c}\text { Energy } \\
\text { (kcal) }\end{array}$ & $\begin{array}{c}\beta \text {-carotene } \\
(\%)\end{array}$ \\
\hline 30 & $10.55^{\mathrm{a}}$ & $1.80^{\mathrm{a}}$ & $4.20^{\mathrm{a}}$ & $7.12^{\mathrm{a}}$ & $81.99^{\mathrm{a}}$ & $51.78^{\mathrm{a}}$ & $21.82^{\mathrm{a}}$ & $1.44^{\mathrm{a}}$ & $357.80^{\mathrm{a}}$ & $0.14^{\mathrm{a}}$ \\
\hline 40 & $9.19^{\mathrm{b}}$ & $2.09^{\mathrm{a}}$ & $4.42^{\mathrm{a}}$ & $7.19^{\mathrm{a}}$ & $82.83^{\mathrm{ab}}$ & $52.06^{\mathrm{b}}$ & $22.69^{b}$ & $1.48^{\mathrm{a}}$ & $362.25^{\mathrm{b}}$ & $0.23^{\mathrm{a}}$ \\
\hline 50 & $8.74^{\mathrm{c}}$ & $2.10^{\mathrm{a}}$ & $4.42^{\mathrm{a}}$ & $7.46^{\mathrm{a}}$ & $83.49^{b}$ & $54.14^{\mathrm{b}}$ & $23.40^{\mathrm{b}}$ & $1.37^{\mathrm{a}}$ & $363.78^{b}$ & $0.09^{\mathrm{a}}$ \\
\hline
\end{tabular}

Different superscript letters in one column show significant differences at the $5 \%$ level.

Table 5 shows the increase in drying temperature in canistel fruit flour processing has no significant effect on ash, protein, sugar, fat, and beta-carotene contents. Buckle et al. (1985) explained that ash content would affect the quality of potato starch, especially color and mineral content. This is consistent with the beta-carotene content in canistel fruit flour which is not significantly different at various drying temperatures. According 
to Yuniarti et al. (2013), increasing the drying temperature would damage the protein. However, in this study, temperature differences do not affect the protein content. This is caused by the drying temperatures used in this study that were quite low $\left(30^{\circ} \mathrm{C}\right.$ to $\left.50^{\circ} \mathrm{C}\right)$. deMan et al. (2018) stated that the temperature range during denaturation and coagulation of most proteins occurred at temperatures of $55^{\circ} \mathrm{C}$ to $75^{\circ} \mathrm{C}$. Drying at $30^{\circ} \mathrm{C}$ to $50{ }^{\circ} \mathrm{C}$ does not cause differences in the fat content of canistel fruit flour, which means that during the drying process, there is no damage to the fat, either hydrolysis or oxidative. Drying duration and interaction between drying temperature and duration do not affect the chemical properties of ripe canistel fruit flour.

Increasing the drying temperature of the canistel fruit flour process has a significant effect on moisture, carbohydrate, starch, and total energy contents. It causes low moisture content of canistel fruit flour. Taib et al. (1988) stated that the ability of the material to release water from the surface was greater by increasing the air-drying temperature and duration. According to Jindal \& Siebenmorgen (1987), the use of high temperatures in the drying process would accelerate the decrease in moisture content. In addition, canistel fruit flour with a drying temperature of $30^{\circ} \mathrm{C}$ has the lowest carbohydrate content and tends to increase at higher temperatures. Desrosier (1988) reported that during the drying process, food material would lose its moisture content causing an increase in nutrient levels in the remaining mass. The amount of available carbohydrate or starch per weight unit in dry food materials will be greater than those in fresh food materials. As with carbohydrate levels, canistel fruit flour of $30^{\circ} \mathrm{C}$ has the lowest starch content. Increasing in starch content due to higher temperature is caused by the reducing process of moisture content. In addition, the temperatures used in the drying process do not cause damage to the starch. Martunis (2012) explained that the starch content in potato decreased when drying was conducted at a temperature of $60^{\circ} \mathrm{C}$.

Based on the physical and chemical properties of canistel fruit flour, it can be concluded that the drying temperature influences the yield, moisture, carbohydrate, fiber, starch, and energy contents. However, it does not affect the bulk density, protein, fat, ash, sugar, and beta-carotene contents. Drying duration of 6 and 8 hours do not affect the physical and chemical qualities of canistel fruit flour. Table 5 shows that chemical properties of canistel flour dried at temperatures of $40{ }^{\circ} \mathrm{C}$ and $50{ }^{\circ} \mathrm{C}$ are not significantly different and better than those at the temperature of $30^{\circ} \mathrm{C}$, so that the selected drying property, based on the data, is a drying temperature of $40{ }^{\circ} \mathrm{C}$ for 6 hours. In addition, the soaking process in $\mathrm{NaCl}$ solution of $7.5 \%$ for 30 minutes, followed by drying at $40{ }^{\circ} \mathrm{C}$ for 6 hours gives the best flour quality in this study.

\section{Conclusion}

Soaking process of canistel fruit in $\mathrm{NaCl}$ and citric acid solution can reduce the contents of alkaloids and flavonoids, which reduce the bitter taste. In addition, the use of $\mathrm{NaCl}$ solution can maintain the orange color of canistel fruit. In contrast, soaking in citric acid can fade the orange color on canistel fruit. The drying temperature has a significant effect on color sensory quality, yield, moisture, carbohydrate, fiber, starch, and total energy contents. However, there was no significant effect on bulk density, ash, fat, protein, sugar, and beta-carotene contents. The selected treatment that improved the physical and chemical quality of canistel fruit flour in this study was the soaking process in $\mathrm{NaCl}$ solution with a concentration of $7.5 \%$ for 30 minutes followed by a drying process at $40{ }^{\circ} \mathrm{C}$ for 6 hours.

\section{Acknowledgements}

This work was funded by Grant of Penelitian Dasar Unggulan Perguruan Tinggi (PDUPT) with contract number 0826/K4/KM/2018 from Ministry of Research, Technology, and Higher Education, Republic of Indonesia. 


\section{References}

Association of Official Analytical Chemists - AOAC. (2010). Official methods of analysis of the Association of Official Analytical Chemists (18th ed., 1 v.). Gaithersburg: AOAC.

Badan Standardisasi Nasional. (2011). Standar Nasional Indonesia 3451: 2011 tentang Tapioka. Jakarta.

Buckle, K. A., Edwards, R. A., Fleet, G. H., \& Wootton, M. (1985). Food science. Jakarta: UI Press.

Clifford, I. O., Kingsley, E., Chika, C. O., \& Chinyere, I. I. (2014). Effects of osmotic dewatering and oven drying on $\beta$-carotene content of sliced light yellow-fleshed sweet potato (Ipomea batatas I.). Nigerian Food Journal, 32(2), 25-32. http://dx.doi.org/10.1016/S0189-7241(15)30114-4

Costa, T. S. A., Wondracek, D. C., Lopes, R. M., Vieira, R. F., \& Ferreira, F. R. (2010). Carotenoids composition of canistel (Pouteria campechiana (Kunth) Bachni). Revista Brasileira de Fruticultura, 32(3), 903-906. http://dx.doi.org/10.1590/S010029452010005000083

Crozier, A., Clifford, M. N., \& Ashihara, H. (2006). Plant secondary metabolites: Occurrence structure, and role in the human diet. lowa: Blackwell Publishing. http://dx.doi.org/10.1002/9780470988558.

deMan, J. M., Finley, J. W., Hurst, W. J., \& Lee, C. Y. (2018). Principles of food chemistry (4th ed.). Switzerland: Springer International Publishing.

Desrosier, N. W. (1988). The technology of food preservation. Westport Connecticut: The Publishing Company.

Fennema, O. R. (1996). Food chemistry (3rd ed.). New York: Marcel Dekker.

Indrajaya, D. (2017). Sifat fisikokimia tepung buah alkesa (Thesis). Faculty of Halal Food Science, Djuanda University, Bogor

Jindal, V. K., \& Siebenmorgen, T. J. (1987). Effect of oven drying temperature and drying time on rough rice moisture content determination. American Society of Agricultural Engineers, 30(4), 1185-1192. http://dx.doi.org/10.13031/2013.30542

Kong, K. W., Khoo, H. E., Prasad, N. K., Chew, L. Y., \& Amin, I. (2013). Total phenolics and antioxidant activities of Pouteria campechiana fruit parts. Sains Malaysiana, 42, 123-127.

Kurozawa, L. E., Morassi, A. G., Vanzo, A. A., Park, K. J., \& Hubinger, M. D. (2009). Influence of spray drying conditions on physicochemical properties of chicken meat powder. Drying Technology, 27(11), 1248-1257. http://dx.doi.org/10.1080/07373930903267187

Lanerolle, M., Priyadarshani, A. M., Sumithraarachchi, D. B., \& Jansz, E. R. (2008). The carotenoids of Pouteria campechiana (Sinhala: ratalawulu). Journal of the National Science Foundation of Sri Lanka, 36(1), 95-98. http://dx.doi.org/10.4038/jnsfsr.v36i1.136

Lidiasari, E., Syafutri, M. I., \& Syaiful, F. (2006). Pengaruh suhu pengeringan tepung tapai ubi kayu terhadap mutu fisik dan kimia yang dihasilkan. Jurnal IImu-IImu Pertanian Indonesia, 8, 141-146.

Lim, T. K. (2012). Edible medicinal and non-medicinal plants. New York: Springer.

Makkar, H. P. S., Aregheore, E. M., \& Becker, K. (1999). Effects of saponins and plant extracts containing saponins on the recovery of ammonia during urea ammoniation of wheat straw and fermentation kinetics of the treated straw. Journal of Agricultural Science, 132(3), 313-321. http://dx.doi.org/10.1017/S0021859699006334

Malinao, B. C., Arquiza, E., Cardinal, K. V., Borgonia, K. D., \& Minoza, J. M. (2017). Development of canistel into ketchup (Thesis). College of Hotel and Restaurant Management, University of Cebu, Baniland, Philippine.

Martunis, M. (2012). Pengaruh suhu dan lama pengeringan terhadap kuantitas dan kualitas pati kentang varietas granola. Jurnal Teknologi dan Industri Pertanian Indonesia, 4, 26-30.

Mayasari, N. (2010). Pengaruh penambahan larutan asam dan garam sebagai upaya reduksi oksalat (Thesis). Faculty of Agricultural Technology, IPB University, Bogor.

Mehraj, H., Sikder, R. K., Mayda, U., Taufique, T., \& Uddin, J. (2015). Plant physiology and fruit secondary metabolites of canistel (Pouteria campechiana). World Applied Sciences Journal, 33, 1908-1914.

Meilgaard, M., Civille, G. V., \& Carr, B. T. (1999). Sensory technique evaluation (3rd ed.). Boca Rabon: CRC Press LLC. http://dx.doi.org/10.1201/9781439832271.

Morton, J. F. (1987). Fruits of warm climates. Miami: Julia F. Morton.

Okezie, B. O., \& Bello, A. B. (1988). Physicochemical and functional properties of winged bean flour and isolate compared with soy isolate. Journal of Food Science, 53(2), 450-454. http://dx.doi.org/10.1111/j.1365-2621.1988.tb07728.x

Paragados, D. A. (2014). Acceptability of canistel (Lucuma nervosa A.DC) fruit flour in making cookies. Asia Pacific Journal of Multidisciplinary Research, 2, 66-73.

Pertiwi, S. R. R., Aminullah, A., Hutami, R., \& Nirmala, D. (2018). Application of non-gluten canistel (Pouteria campechiana) flour-maizena mocaf-tapioca composite on the processing of steamed brownies. Jurnal Agroindustri Halal, 4(2), 153-161. http://dx.doi.org/10.30997/jah.v4i2.1279

Robinson, T. (1995). Kandungan organik tumbuhan tinggi (6th ed.). Bandung: ITB Press.

Suprapto, H. (2006). Pengaruh perendaman pisang kepok (Musa acuminax balbisiana Calla) dalam larutan garam terhadap mutu tepung yang dihasilkan. Jurnal Teknologi Pertanian, 1, 74-80.

Taib, G., Said, G., \& Wiaatadja, S. (1988). Operasi pengeringan pada pengolahan hasil pertanian. Jakarta: PT Mediatama Sarana Perkasa. 
Optimization on process of ripe canistel (Pouteria campechiana) fruit flour based on several quality characteristics

Pertiwi, S. R. et al.

Widiawan, I. M. E., Nocianitri, K. A., \& Putra, N. K. (2013). Karakterisasi sifat fisiko kimia pati talas kimpul (Xanthosoma sagittifolium) termodifikasi dengan metode asetilasi. Jurnal ITEPA, 2, 1-10.

Winarno, F. G. (1997). Kimia pangan dan gizi. Jakarta: Gramedia Pustaka Utama.

Yuniarti, D. S., Sulistiyati, T. D., \& Suprayitno, E. (2013). Pengaruh suhu pengeringan vakum terhadap kualitas serbuk albumin ikan gabus (Ophiocephalus striatus). THPi Student Journal, 1, 1-9.

Funding: Ministry of Research, Technology, and Higher Education, Republic of Indonesia (0826/K4/KM/2018). 